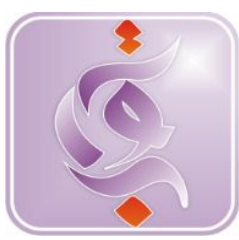

\title{
GAMBARAN AKTUALISASI DIRI PENYANDANG TUNA NETRA (Studi pada Boy Sandi Penyanyi Minang)
}

Received: $27^{\text {th }}$ December 2017; Revised: 09 th January 2018; Accepted: $19^{\text {th }}$ February 2018

\section{Hasneli \\ UIN Imam Bonjol Padang \\ Email: hasnelim17@,gmail.com}

Fitra Meri Aulia Riska

UIN Imam Bonjol Padang

\begin{abstract}
Abstrak : Penderita tuna netra sejak lahir, dengan berbagai kemampuan yang dimilikinya mampu mengaktualisasikan dirinya dengan baik. Dia bangkit dengan terus menggali potensi-potensi yang terdapat dalam dirinya dan berupaya mengembangkan potensi tersebut semaksimal mungkin walaupun berawal dari ketidakmungkinan dan menghadapi berbagai rintangan, yang berat, akan tetapi semua proses yang dilalui akhirnya mengantarkannya kepada pencapaian aktualisasi diri yang baik. Penelitian ini bertujuan untuk mengetahui gambaran aktualisasi diri yang dilakukan oleh Boy Sandi dan faktor yang mendorong Boy Sandi mengaktualisasikan diri. Penelitian ini menggunakan metode kualitatif, dengan teknik purposive sampling sebagai penetapan sampel. Subjek dalam penelitian ini adalah Boy Sandi dan sebagai informan adalah istri Boy Sandi, ibu mertua dan tetangganya. Teknik pengumpulan data yaitu observasi dan wawancara. Hasil penelitian menunjukkan bahwa Boy Sandi mampu mencapai tingkat kebutuhan tertinggi yaitu aktualisasi diri. Dalam hal ini Boy Sandi adalah orang yang terbuka pada pengalaman, memiliki kehidupan eksistensial, memiliki kepercayaan diri, kreatif, spontanitas dan memiliki sifat humor. Faktor yang mendorong Boy Sandi mampu mengaktualisasikan diri adalah karena Boy Sandi mampu menerima takdir Allah tanpa menyesali diri dengan kekurangan yang dimiliki disertai dengan keinginan dari dalam diri, kegigihan, semangat, citacita. Di samping itu karena faktor ekonomi dan orientasi masa depan serta adanya dukungan sosial dari orang-orang terdekatnya.
\end{abstract}

Kata Kunci : Aktualisasi Diri, Tuna Netra

\section{PENDAHULUAN}

Setiap orang memiliki keinginan, harapan dan cita-cita yang tinggi. Untuk mencapai keinginan dan harapan tersebut akan mendorong dirinya untuk menggapai apa yang diinginkan dengan cara menggali potensi-potensi yang terdapat dalam diri. Akan tetapi potensi tersebut tidak akan sempurna jika tidak dikembangkan dengan baik dan semaksimal mungkin. Upaya yang dilakukan seseorang untuk menggali dan mengembangkan potensi diri dinamakan dengan aktualisasi diri.

Maslow dalam Syafitri (2014: 292) mengatakan bahwa aktualisasi diri adalah keinginan seseorang untuk memperoleh kepuasan atas diri sendiri (self fulfilment) menyadari semua potensi diri, menjadi apa yang dapat ia lakukan, dan menjadi kreatif dan bebas mencapai puncak prestasi dan potensi. Karena pada dasarnya setiap manusia memiliki potensi yang dibawa sejak 
lahir, salah satu untuk mencapai potensi tersebut adalah dengan cara mengaktualisasikan diri.

Terdapat dua motif yang berkaitan dengan kebutuhan aktualisasi diri yakni kompetensi dan prestasi. Motif kompetensi terungkap dengan sendirinya pada dewasa ketika tumbuh hasrat untuk menguasai pekerjaan dan keahlian tertentu. Motif prestasi, orang-orang bermotivasi prestasi cenderung melakukan hal positif untuk mencapai cita-cita. Karena mereka merasa bahwa upaya dan kemampuan mereka kemungkinan akan mempengaruhi hasil usahanya (Yonanda, Susilo dan Prasetya, 2016: 111).

Sebagaimana yang dikatakan Bums dalam Muryatiningsih (2013: 44) dengan kepercayaan diri yang cukup, seseorang individu akan dapat mengaktualisasikan potensi yang dimilikinya dengan yakin dan mantap. Sehingga keberhasilan seseorang dalam mencapai aktualisasi diri menandakan bahwa dia termasuk orang yang sehat, seperti yang disampaikan oleh Maslow bahwa orang-orang yang sehat adalah orang yang mengaktualisasikan dirinya.

Akan tetapi proses aktualisasi diri yang dilakukan oleh orang normal akan berbeda dengan orang yang memiliki keterbatasan dan kekurangan terutama dalam segi penglihatan, dimana mata adalah organ dan alat indra terpenting bagi manusia. Dengan mata seseorang dapat melihat dunia, mereka yang memiliki keterbatasan dan kekurangan tersebut juga mempunyai harapan dan cita-cita yang tinggi, walaupun pada dasarnya apa yang diinginkan tersebut terhalang oleh keterbatasan dan kekurangan dari segi penglihatan.

Kelainan penglihatan dan ketidakmampuan untuk melihat dinamakan dengan tuna netra, dimana secara terminologi Sardegna dalam Harimukthi, dan Dewi (2014: 65) menjelaskan bahwa tuna netra adalah individu yang kehilangan penglihatan karena kedua indera penglihatannya tidak berfungsi seperti orang normal.F.H. Sasraningrat dalam Rudiyati (2005:90) juga menyatakan bahwa kekurangan atau keterbatasan tersebut ada yang diderita sejak lahir tetapi ada juga yang dialami setelah mereka remaja atau dewasa. Kondisi ini disebabkan oleh kerusakan mata, syaraf optik atau bagian otak yang menolak stimulus visual.

Bagi penyandang tuna netra dengan kondisi tidak dapat melihat, akan membuat dirinya lemah, merasa tidak berguna dan biasanya tuna netra cenderung untuk menjadikan keterbatasannya sebagai alasan untuk mengasihani diri, merasa tidak bisa melakukan apa-apa, mengubur cita-cita karena kekurangan yang dimilikinya sehingga mereka tidak mampu untuk mengaktualisaskan dirinya dengan baik. Apalagi jika seseorang tersebut tidak dibekali dengan keimanan yang kuat, tidak mampu menerima qadha dan qadhar Allah maka ia akan semakin merasa terpuruk dengan keadaanya.

Namun terdapat sebagian dari tuna netra yang mengalami kebutaan sejak lahir, mampu untuk mengaktualisasikan dirinya dengan baik di samping keterbatasan yang mereka miliki, mereka bangkit dengan terus menggali potensi-potensi yang terdapat dalam dirinya dan berupaya mengembangkan potensi tersebut semaksimal mungkin walaupun berawal dari ketidakmungkinan dan menghadapi berbagai rintangan, hambatan dan kesulitan-kesulitan yang berat, akan tetapi semua proses yang mereka lalui akhirnya mengantarkan mereka kepada pencapaian aktualisasi diri yang baik. Hal ini tidak terlepas dari keyakinan bahwasannya kekurangan dan takdir yang diberikan Allah menyimpan kelebihan yang bisa dikembangkan menjadi lebih baik.

Seperti halnya yang dilakukan oleh seorang tuna netra yang menjadi subjek dalam penelitian ini, subjek yang memiliki nama lengkap 'Boy Sandi' yang saat ini sudah berusia 42 tahun, dimana subjek mengalami kebutaan sejak lahir dengan kondisi kedua kelopak matanya tertutup. Subjek yang berasal dari keluarga sederhana dan merupakan anak ke 2 dari 5 orang bersaudara ini menuturkan bahwa subjek adalah orang yang tidak pernah mengenyam bangku pendidikan dalam artian subjek tidak 
pernah sekolah, dikarenakan keterbatasan yang dialaminya dan juga saat itu belum ada sekolah khusus bagi penyandang tuna netra. Sehingga subjek belajar dari lingkungan, ia berteman dengan anak sekolahan dan belajar banyak hal dari teman-temanya.

Subjek mengatakan bahwa ia adalah orang yang memiliki rasa ingin tahu yang sangat besar. Ia selalu ingin mencoba apa yang orang normal lakukan dan ia tidak ingin menjadikan keterbatasannya sebagai penghambat bagi cita-citanya, karena menurutnya ini semua adalah takdir dari Allah SWT yang harus ia terima. Hal ini diungkapkan subjek saat penulis mewawancarainya pada tanggal 29 September 2017 tepatnya pukul $09.15 \mathrm{~s} / \mathrm{d}$ 11.25 .

\section{KAJIAN TEORI}

\section{Aktualisasi Diri}

Walaupun pada dasarnya mencapai proses aktualisasi diri tidaklah mudah, apalagi bagi mereka yang memiliki keterbatasan dalam hal penglihatan, karena keterbatasan tersebut dimungkinkan menghambat tugas-tugas perkembangannya Delphie dalam Harimukhti dan Dewi (2014:65).

Berdasarkan penjelasan di atas secara umum dapat dipahami bahwa aktualisasi diri merupakan kebutuhan universal yang pasti ada dalam diri individu tidak terkecuali bagi mereka yang mengalami keterbatasan dalam segi penglihatan (tuna netra). Beberapa tuna netra memiliki motivasi aktualisasi yang sangat baik dalam keterbatasan penglihatan mereka, namun beberapa diantaranya pun tetap merasa terpuruk dan tidak mampu melakukan yang terbaik.

Aktualisasi diri adalah keinginan untuk memperoleh kepuasan diri dengan dirinya sendiri (self fulfilment), untuk menyadari semua potensi dirinya, untuk menjadi apa saja yang dia dapat lakukan, dan untuk menjadi kreatif dan bebas mencapai puncak potensinya (Alwisol, 2004:260). Di samping itu aktualisasi diri juga merupakan salah satu kebutuhan yang diharapkan dapat terpenuhi oleh setiap orang Koswara dalam Muryatiningsih (2013: 44). Maslow menandai kebutuhan akan aktualisasi diri sebagai hasrat individu untuk menjadi orang sesuai dengan keinginan dan potensinya.

Menurut Widayanti, dkk (2014: 25) aspek-aspek aktualisasi diri yaitu: terbuka pada pengalaman, kehidupan eksistensial, memiliki rasa kepercayaan baik pada diri sendiri maupun orang lain, bebas, kreatif, spontan dan humor. Menurut Maslow dalam Baihaqi (2008: 204-206) terdapat dua faktor yang memengaruhi aktualisasi diri yaitu, faktor pendorong dan faktor penghambat.

Adapun yang menjadi faktor pendorong aktualisasi diri adalah: 1) Dorongan karena kekurangan, kekurangan yang dimiliki oleh seseorang baik itu kekurangan dari segi kebutuhan fisiologis, rasa aman, memiliki dan cinta, serta kebutuhan akan penghargaan, 2) Memilki kesehatan jiwa yang normal, orang-orang yang memiliki jiwa yang sehat dan normal, mereka menginginkan untuk bisa mengaktualisasikan dirinya dengan sempurna, melakukan lebih baik dari apa yang dia bisa dengan segenap potensi yang ia punya, 3) Keinginan untuk menjadi lebih baik, keinginan seseorang untuk menjadi lebih baik dari keadaan sebelumnya adalah salah satu faktor pendorong dalam proses pencapaian aktualisasi diri. Rasa tidak puas dan rasa ingin menjadi lebih baik akan mendorong seseorang untuk terus berusaha mengembangkan potensi yang dimilikinya, 4) Kegagalan, menurut Maslow kegagalan merupakan salah satu faktor pendorong aktualisasi diri, jika seseorang gagal atas pencapaianya maka ia akan berusaha untuk melakukan yang terbaik, memaksimalkan potensinya agar kegagalan itu tidak terjadi lagi.

Sedangkan faktor penghambat
aktualisasi diri terdiri atas: 1) Ketidakpercayaan dan sinisme, rasa tidak percaya akan kemampuan diri dalam artian 
Hasneli, Fitra Meri Aulia Riska, Gambaran Aktualisasi Diri .... 35

merasa tidak mampu untuk melakukan sesuatu yang lebih baik dan meragukan akan potensi yang dimiliki akan menjadi penghambat bagi seseorang dalam mencapai aktualisasi diri, 2) Pandangan sederhana tentang kehidupan, memandang hidup secara sederhana, tanpa adanya pikiran untuk maju, tidak memiliki cita-cita, tidak memilki keinginan untuk menjadi lebih baik, 3) Kehilangan emosi, kehilangan semangat dan kekosongan pengalaman, dan 4) Putus asa dan berhenti berjuang.

Menurut Maslow dalam Irmawati (2013: 27-28). ada beberapa kriteria orang yang memiliki aktualisasi diri antara lain : Bebas dari psikopatologi atau penyakit psikologis, orang-orang yang mengaktualisasikan diri ini telah menjalani hierarki kebutuhan dan menjunjung prinsipprinsip nilai yang abadi.

\section{Tuna Netra}

Menurut Kamus Besar Bahasa Indonesia kata tuna berarti rusak, luka, cacat, kurang, tidak punya, dan netra memiliki arti mata, jadi tuna netra berarti buta tidak dapat melihat. Secara etimologi kata tuna netra berasal dari tuna yang berarti rusak, netra yang berarti mata atau penglihatan. Tuna netra berarti kondisi luka atau rusaknya mata atau indra penglihatan sehingga mengakibatkan kurang atau tiada memiliki kemampuan persepsi penglihatan (Irmawati, 2013: 2).

Secara terminologi tuna netra adalah seseorang yang memiliki hambatan dalam penglihatan atau tidak berfungsinya indra penglihatan. Sementara itu seseorang dinyatakan tuna netra jika setelah dilakukan upaya perbaikan terhadap kemampuan visualnya, ternyata ketajaman visualnya tidak melebihi 20/200 atau setelah dilakukan upaya perbaikan terhadap kemampuan visualnya ternyata pandangannya tidak melebihi 20 derejat Hallan dan Kauffman dalam Mangunsong (2009: 54).Sedangkan secara fisiologis seseorang dikatakan tuna netra jika bayangan benda yang ditangkap oleh mata tidak dapat diteruskan oleh kornea, lensa mata, retina dan syaraf karena suatu sebab misalnya karena kornea mata mengalami kerusakan, kering, keriput, lensa mata menjadi keruh atau syaraf yang menghubungkan mata dengan otak mengalami gangguan (Efendi, 2006: 30).

\section{METODE}

Jenis penelitian yang dilakukan adalah field research (penelitian lapangan) dengan mengunakan metode kualitatif, yang merupakan suatu prosedur penelitian yang menghasilkan data deskriptif berupa kata yang tertulis atau lisan dari orang yang diteliti. Dalam penelitian ini metode deskriptif adalah data yang dikumpulkan berupa kata-kata, gambaran bukan angkaangka, hasil penelitian tertulis berisi kutipan dari data untuk mengilustrasikan dan menyediakan bukti presentasi (Emzir, 2012:3)

Subjek atau informan penelitian diambil dengan menggunakan teknik purposive sampling, dimana teknik pengambilan sampel ini merupakan suatu teknik untuk menentukan sampel penelitian dengan beberapa pertimbangan tertentu yang bertujuan agar data yang diperoleh lebih representatif. Teknik ini berdasarkan pada ciri-ciri atau sifat tertentu yang berkaitan erat dengan ciri-ciri dan sifat yang ada dalam populasi yang sudah diketahui sebelumnya (Narbuko C, 2016:116). Penelitian ini dilakukan di Wisma Tabing Indah RT.001 RW.006 Kelurahan Gunung Sarik Kecamatan Kuranji Kota Padang Provinsi Sumatera Barat.

Ada dua sumber data dalam penelitian ini, yaitu sumber data primer dan sumber data sekunder. Pertama, sumber data primer merupakan sumber data utama dalam penelitian. Sumber data primer menjadi pokok yang melatarbelakangi semua hal yang akan diteliti. Sumber data primer dalam penelitian ini adalah "Boy Sandi" penyanyi minang tuna netra, Boy Sandi dijadikan sebagai subjek utama dalam penelitian ini karena Boy Sandi adalah orang yang memenuhi kriteria dari aktualisasi diri Abraham Maslow. Yang beralamat di Wisma Tabing Indah Kelurahan Gunung Sarik Kecamatan Kuranji Kota Padang. Kedua, 
sumber data sekunder merupakan sumber data yang diperoleh setelah terkumpulnya sumber data primer guna melengkapi sekaligus memperkuat sumber data primer. Sumber data sekunder akan memperjelas dan mempertajam segala hal yang didapat dari sumber data primer. Sumber data sekunder dalam penelitian ini ialah sumber data yang diperoleh dari pihak kedua yaitu istri subjek, mertua subjek dan tetangga subjek.

Teknik pengumpulan data yang penulis gunakan dalam penelitian ini yaitu: Observasi, menurut Hadi dalam Sugiyono (2010:145) observasi merupakan suatu proses yang kompleks dan tersusun dari berbagai proses biologis dan psikologis. Tujuan observasi ialah mendeskripsikan setting yang dipelajari, aktifitas yang berlangsung, orang-orang yang terlibat dalam aktifitas dan makna kejadian dilihat dari prespektif mereka yang terlibat dalam kejadian yang dialami tersebut. Dalam teknik observasi atau pengamatan ini dilakukan untuk mengamati perilaku subjek yang berkaitan dengan gambaran aktualisasi diri, yang dilakukan oleh "Boy Sandi" penyanyi minang tuna netra. Wawancara, menurut Moleong (2017:186) wawancara merupakan percakapan dengan maksud tertentu. Percakapan itu dilakukan oleh dua pihak yaitu pewawancara (penulis) mengajukan pertanyaan terhadap terwawancara (informan) yang memberikan jawaban atas pertanyaan. Jenis wawancara yang digunakan dalam penelitian ini adalah wawancara bebas terstruktur yang termasuk dalam kategori mendalam (in-depth interview) yaitu punya pedoman tapi memikirkan pertanyaan sesuai dengan situasi dan kondisi. Pelaksanaannya lebih bebas dibandingkan dengan wawancara terstruktur (Sugiyono, 2010:233). Peneliti melakukan wawancara terhadap penyanyi minang tuna netra "Boy Sandi", istri dan mertua yang bersangkutan serta tetangga subjek.

Teknik Analisis Data, menurut Miles dan Huberman dalam Emzir (2012: 129-135) terdapat tiga teknik dalam analisis data kualitatif yaitu: 1. Reduksi Data, yaitu merangkum, memilih hal-hal yang pokok, memfokuskan pada hal-hal yang penting, dengan demikian data yang telah direduksi akan memberikan gambaran yang lebih jelas dan mempermudah peneliti untuk melakukan pengumpulan data selanjutnya dan menariknya bila diperlukan. 2. Data Display, dalam data display penyajian data bisa dilakukan dalam bentuk uraian singkat, bagan, hubungan antara kategori flowchart dan sejenisnya. Dengan mendisplay data maka akan memudahkan untuk memahami apa yang terjadi. 3. Menarik Kesimpulan.

\section{HASIL PENELITIAN DAN PEMBAHASAN}

\section{Hasil Penelitian}

Setelah dilakukan observasi dan wawancara kepada Boy Sandi dan istri Boy Sandi, mertua serta tetangga Boy Sandi di dapatkan hasil bahwasannya Boy Sandi adalah orang yang mengaktualisasikan diri tergambar dari sikapnya yang terbuka pada pengalaman, kehidupannya eksistensial terlihat dari banyaknya penggemar yang dimiliki Boy Sandi, mempunyai rumah mewah, mobil dll, memiliki kepercayaan diri yang tinggi di samping keterbatasan yang dimilikinya, memiliki sifat humor, spontanitas terhadap sesuatu, kreatif, terbukti dari banyaknya karya karya dalam bentuk album lagu, aransemen musik yang ia hasilkan.

Faktor yang mendorong Boy Sandi mengaktualisasikan diri ada dua yang pertama yaitu faktor internal yang terdiri atas, menerima ketetapan dan takdir dari Allah dengan disertai keinginan untuk maju dan sukses yang berasal dari dalam diri Boy Sandi, kegigihan yang sejak kecil sudah dimilikinya, harapan dan cita-cita yang tinggi, di samping itu karena kekurangan dan keterbatasannya sebagai tuna netra yang tidak mampu melihat sehingga hal itu mendorongnya untuk berupaya mencari kelebihannya dan memaksimalkan kelebihan tersebut. Dan yang terpenting adalah kepercayaan diri yang tinggi yang dimiliki oleh Boy Sandi, walaupun ia netra tetapi ia 
percaya diri akan kemampuannya. Yang kedua adalah faktor eksternal, dimana faktor eksternal yang mendorong Boy Sandi untuk mengaktualisasikan diri adalah karena faktor ekonomi serta dorongan, motivasi dan bantuan dari orang terdekatnya.

\section{Pembahasan}

Menurut Goldstein dalam Ghofur (2006: 27) salah satu pengembang teori organismik menyatakan bahwa aktualisasi diri adalah motivasi utama (dorongan utama individu) yang berarti bahwa manusia terus menerus berusaha merealisasikan potensipotensi yang terdapat dalam dirinya, dalam setiap kesempatan yang terbuka bagi dirinya. Berdasarkan tujuan utama inilah yang nantinya mampu memberikan arah dan kesatuan pada kehidupan seseorang. Aktualisasi diri juga merupakan kebutuhan tertinggi dari hirarki kebutuhan manusia.

Pengaktualisasian diri bertujuan agar mereka dapat mengungkapkan potensipotensi yang terdapat dalam dirinya. Penyaluran aktualisasi diri dapat berupa penciptaan kreasi atau karya-karya berdasarkan bakat yang dimiliki. Seseorangpun dapat mengaktualisasikan diri dengan jalan membuat yang terbaik atau bekerja dengan sebaik-baiknya sesuai dengan bidangnya masing-masing. Selain itu dengan mengaktualisasikan diri seseorang akan merasa berguna, percaya diri dan berharga (Widayanti, 2014: 25).

Boy Sandi yang memiliki sifat terbuka pada pengalaman dimana ia memiliki hubungan sosial dan cara interaksi sosial yang baik dengan orang-orang disekelilingnya sebagaimana Malow mengungkapkan bahwa sikap yang diharapkan ada pada orang yang mengaktualisasikan diri salah satunya adalah terbuka pada pengalaman (Soetanto, 2016:14). Dan menurut Anari dalam Soetanto (2016: 15-16) mengungkapkan bahwa seseorang yang mengaktualisasikan diri berarti mampu menjalin hubungan yang baik dengan orang yang berada di sekitarnya.

Boy Sandi juga memiliki kehidupan eksistensial dibuktikan dengan banyaknya penggemar yang ia miliki dan Boy Sandi selalu mengikuti perkembangan zaman. Di samping itu kondisi ekonominya yang saat ini berdada di taraf menengah ke atas, Boy Sandi memiliki mobil, memiliki rumah dan kebutuhan hidup yang berkecukupan. Boy Sandi juga merupakan orang yang kreatif, dibuktikan dengan banyaknya karya-karya yang ia hasilkan baik dalam bantuk lagu maupun aransemen musik. Maslow (2017:254) mengungkapkan bahwa kreativitas adalah karakter umum dari orang yang mengaktualisasikan diri. Boy Sandi juga merupakan orang yang menyukai kebebasan dimana ia tidak ingin terikat dan terkekang dengan apapun apalagi dalam hal pekerjaan.

Selain itu Boy Sandi adalah orang yang memiliki kepercayaan diri yang tinggi dan itu menjadi modal besar baginya untuk bangkit dan maju di samping dengan keterbatasan yang ia miliki. Sebagaimana Anari dalam Soetanto (2016:15) mengungkapkan bahwa seseorang yang mengaktualisasikan dirinya berarti mampu menjadi diri sendiri dan tidak terpengaruh oleh perkataan orang lain. Boy Sandi juga merupakan orang yang memiliki sifat humor dan ini merupakan salah satu cirri-ciri orang yang mengaktualisasikan diri. Sebagaimana menurut Maslow (2017:253) bahwa humor yang dilakukan oleh orang yang mengaktualisasikan diri dapat berupa lelucon pada diri sendiri tetapi tidak dilakukan dengan cara yang menyakitkan. Humor orang yang mengaktualisasikan diri adalah humor tentang realitas.

Boy Sandi juga memiliki sifat spontanitas jika hal itu sesuai dengan kemampuannya dan bisa ia lakukan sebagaimana Maslow (2017:237) mengungkapkan bahwa orang yang tengah mengaktualisasikan diri secara relatif dapat digambarkan sebagai mereka yang selalu spontan dalam perilakunya, bahkan dalam kejiwaannya, pikirannya, impulsnya, dan sebagainya. Perilaku mereka ditandai oleh kesederhanaan dan kewajaran dan bukan oleh sikap pura-pura dan gengsi. 
Faktor yang mendorong Boy Sandi untuk mengaktualisasikan diri ada dua yaitu faktor internal dan eksternal. Faktor internal adalah faktor yang berasal dari dalam diri Boy Sandi, Faktor internal tersebut yang paling utama adalah karena Boy Sandi mampu menerima takdir dari Allah tanpa menyesali kekurangannya di sertai dengan dirinya yang memiliki keinginan besar untuk maju dan sukses, kegigihan yang dimiliki, cita-cita dan semangat untuk menggali dan mengembangkan potensi tersebut. Boy Sandi yang juga memiliki rasa ingin tau yang tinggi sehingga ia tidak menyerah dan terus berjuang. Di samping itu kepercayaan diri yang tinggi yang dimilikinya sehingga ia tidak menjadikan kekurangan tersebut sebagai alasan dan penghambat. Tidak hanya itu kekurangan yang dimilikinya juga menjadi pendorong baginya untuk mengaktualisasikan diri. Karena dengan ketidakmampuan melihat itulah yang membuat Boy Sandi mencari kelebihannya dan mengembangkannya hingga ia bisa meraih apa yang ia inginkan.

Sebagaimana yang di ungkapkan oleh Maslow bahwasannya orang-orang yang sehat yaitu orang yang mengaktualisasikan diri akan berusaha memenuhi potensi-potensi mereka dengan tujuan untuk memperkaya dan memperluas pengalaman hidup, meningkatkan kesenangan dan mencapai cita-cita yang diinginkannya (Baihaqi, 2008: 204). Faktor eksternal yang mendorong Boy Sandi untuk mengaktualisasikan diri adalah karena faktor ekonomi, dimana Boy Sandi yang berasal dari keluarga yang sederhana. Ayahnya berprofesi sebagai penjual sate, dan Boy Sandi merupakan anak ke 2 dari 5 orang bersaudara. Keadaan ekonomi yang belum mencukupi mendorong Boy Sandi untuk berusaha sesuai dengan apa yang ia bisa.

Di samping itu dukungan sosial dari orang-orang terdekat Boy Sandi juga memiliki peranan penting dalam mencapai aktualisasi diri, dimana isterinya yang selalu menemani Boy Sandi kemanapun pergi, orang tua serta rekan kerja Boy Sandi. Tidak hanya itu Boy Sandi juga berfikir untuk masa depannya, dimana ia juga berkeinginan hidup lebih baik, ingin memiliki istri dan anak. Sehingga hal itu menjadi pendorong bagi Boy Sandi untuk mengembangkan kemampuannya hingga mencapai kesuksesan. Sebagaimana yang diungkapkan oleh Maslow, bahwasannya seseorang akan terdorong untuk mengaktualisasaikan diri karena kekurangan yang dimilikinya, dorongan semacam itu direncanakan untuk mencapai sesuatu yang kurang pada diri seseorang. Dan menurut Maslow orang yang memiliki kesehatan jiwa yang normal akan terdorong dan berjuang untuk memuaskan kebutuhannya (Baihaqi, 2008: 204).

\section{KESIMPULAN}

Berdasarkan uraian yang dipaparkan di atas maka dapat ditarik beberapa kesimpulan:

1. Gambaran aktualisasi diri yang dilakukan oleh Boy Sandi dapat dilihat dari terpenuhinya aspek-aspek yang terdapat dalam aktualisasi diri itu sendiri. Hal ini dibuktikan dengan sikap Boy Sandi yang terbuka pada pengalaman, memiliki kehidupan eksistensial. Memiliki rasa kepercayaan diri yang tinggi yang menjadi modal besar bagi Boy Sandi untuk mengaktualisasikan diri. Boy Sandi juga merupakan orang yang kreatif, terbukti dari karya-karya yang ia hasilkan. Selanjutnya yaitu spontanitas yang merupakan sikap siap melakukan apa saja dan hal itu dimiliki oleh Boy Sandi dan Boy Sandi juga memiliki sifat humor.

Faktor yang mendorong Boy Sandi untuk mengaktualisasikan diri ada dua yaitu faktor internal dan faktor eksternal. Faktor internal adalah karena Boy Sandi mampu menerima takdir Allah tanpa menyesali kekurangannya disertai dengan dirinya yang berkeinginan untuk maju, kegigihan, semangat, cita-cita dan rasa ingin tahu yang tinggi di samping itu karena kekurangan/keterbatasannya sebagai tuna netra sehingga membuat ia berusaha menjadikan dirinya lebih baik. Boy Sandi juga memiliki kepercayaan diri yang 
Hasneli, Fitra Meri Aulia Riska, Gambaran Aktualisasi Diri ... 39

tinggi untuk terus berusaha menggapai citacita. Sedangkan faktor eksternal yang mendorong Boy Sandi untuk mengaktualisasikan diri adalah faktor ekonomi keluarga yang kurang mencukupi sehingga mendorong Boy Sandi untuk berusaha lebih giat lagi dan orientasi pemikirannya dimasa yang akan datang, dimana Boy Sandi ingin menjadi sukses dan menghasilkan uang tanpa dihambat oleh kekurangannya serta dibantu oleh dukungan sosial dari orang-orang terdekatnya.

\section{DAFTAR KEPUSTAKAAN}

. Alwisol. (2004). Psikologi Kepribadian. Malang: UMM Press.

Baihaqi, Mif. (2008). Psikologi Pertumbuhan. Bandung: Remaja Rosda karya.

Departeman RI. (2004). Alqur'an dan Terjemahan. Bandung: Jumanatul Ali-Art.

Dianingtyas, Azizah. (2014). Pengaruh Penghargaan dan Kebutuhan Aktualisasi Diri Terhadap Prestasi Kerja Karyawan Pada PT. Telkom Yogyakarta. Yogyakarta: Universitas Negeri Yogyakarta.

Efendi, Mohammad. (2006). Pengantar Psikopedagogik Anak Berkelainan. Jakarta: Bumi Aksara.

Feist, Jess dan Feist Gregory J. (2010). Teori Kepribadian. Jakarta: Salemba Humanika.

Fithriyah Chusniatul dan Rahayu Siti Azizah. (2013). Konsep Diri Pada Remaja Tuna Netra Di Yayasan Pendidikan Anak Buta (YPAB) Surabaya. Jurnal Pendidikan Psikologi, Vol.04 No. 01.

Ghofur, O. (2006). Konsep Aktualisasi Diri Abraham. H. Maslow Dan Korelasinya Dalam Pembentukan Kepribadian (Analisis Bimbingan Dan Konseling Islam). Skripsi. Semarang: Institut Agama Islam Negeri Walisongo.

Harimukhti Mega Taladan Dewi Kartika Sari. (2014). Eksplorasi Kesejahteran Psikologis Individu Dewasa Awal
Penyandang Tuna Netra. Jurnal Psikologi Undip, Vol. 13 No. 1.

Irmawati, Nooryani. (2013). Motivasi Aktualisasi Diri Penyandang Tuna Netra Pada Ikatan Tuna Netra Muslim Indonesia Kota Yogyakarta. Yogyakarta: Fakultas Dakwah Dan Komunikasi Universitas Islam Negeri Sunan Kalijaga Yogyakarta.

Khoiroh Atik dan Paramita Pramesti P. (2014). Peran Dukungan Sosial Terhadap Pembentukan Self Esteem yang Tinggi pada Remaja Tunanetra di Sekolah Khusus. Jurnal Psikologi Industri dan Organisasi, Vol. 3 Nol. 3.

Mangunsong, Frieda. (2009). Psikologi dan Pendidikan Anak Berkebutuhan Khusus jilid 1.Depok : LPSP3UI.

Marlina. (2009). Asesmen Pada Anak Berkebutuhan Khusus. Padang: UNP Press.

Maslow, Abraham H. (2017). Motivation And Personality. Yogyakarta: Cantrik Pustaka.

Moleong, Lexy J. 2017. Metodologi Penelitian Kualitatif. Bandung: Remaja Rosda karya.

Muryatiningsih, Asri Priyani. (2013). Hubungan Antara Kepercayaan Diri Dengan Aktualisasi Diri Pada Remaja Di Desa Puhrubuh Condong-Catur depok Sleman Yogyakarta. Jurnal Ilmu-Ilmu Kesehatan Surya Medika, Vol. 9 No. 1.

Narbuko, C \& Achmad, A. (2016). Metodologi Penelitian. Jakarta: Bumi Aksara

Ni'matuzahroh \& Prasetyaningrum. (2014). Observasi Dalam Psikologi. Malang: UMM Press.

Putri, Desytama Tika. (2007). Kebutuhan Aktualisasi Diri Pada Remaja Penyandang Tuna Netra Yang Bersekolah Di Sekolah Umum Di Tinjau Dari Kematangan Emosi dan Self Disclosure. Surakarta: Fakultas 
Psikologi UMS (Diakses pada http://eprints.ums.pdf.ac.id10 Oktober 2017)

Rudiyati Sari. (2005). Pengembangan Materi Alat Bantu Pembelajaran Anak Tuna Netra Di Sekolah Terpadu /Inklusi. Jurnal Pendidikan Khusus, Vol.1 No. 2.

Soetanto, Christian. (2016). Aktualisasi Diri Wanita Karir yang Mengurus Rumah Tangga. Yogyakarta: Universitas Sanata Dharma.

Sugiyono. (2010). Metode Penelitian Kuantitatif Kualitatif R\&D. Bandung: Alfabeta.

Syafitri, Selviana. (2014). Pengaruh Harga Diri Dan Kepercayaan Diri Dengan Aktualisasi Diri Pada Komunitas Modern Dance Di Samarinda. Ejurnal Psikologi, Vol. 2 No. 2.
Syarif, Makmur (2014). Pedoman Penulisan Karya Ilmiah. IAIN Imam Bonjol Padang.

Tohirin. (2013). Metode Penelitian Kualitatif. Jakarta: Rajawali Pers.

Widayanti, Nusantoro Eko dan Kurniawan Kusnarto. (2014). Peningkatan Aktualisasi Diri Sebagai Dampak Layanan Penguasaan Konten. Semarang: Indonesian Journal of Guidance and Counseling Theory and Aplication.

Yonanda Cintya, Susilo Heru dan Prasetya Arik. (2016). Pengaruh Kebutuhan Fisiologis, Keamanan, Sosial, Penghargaan, Dan Aktualisasi Diri Terhadap Prestasi Kerja Karyawan. Jurnal Administrasi Bisnis (JAB), Vol. 30 No. 1.

(Http://eprints.ums.pdf.ac.id (diakses pada 10 Oktober 2017). 